Journal of the Society for the Study of Architecture in Canada Le Journal de la Société pour l'étude de l'architecture au Canada

\title{
The Late Nineteenth-century Stone Farmhouses of John Thompson Crellin
}

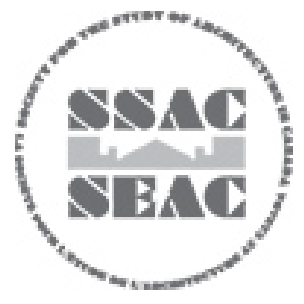

\section{Karen Elisabeth Armstrong}

Volume 43, numéro 2, 2018

URI : https://id.erudit.org/iderudit/1058037ar

DOI : https://doi.org/10.7202/1058037ar

Aller au sommaire du numéro

Éditeur(s)

SSAC-SEAC

ISSN

2563-8696 (numérique)

Découvrir la revue

Citer cet article

Armstrong, K. E. (2018). The Late Nineteenth-century Stone Farmhouses of John Thompson Crellin. Journal of the Society for the Study of Architecture in Canada / Le Journal de la Société pour l'étude de l'architecture au Canada, 43(2), 27-41. https://doi.org/10.7202/1058037ar d'utilisation que vous pouvez consulter en ligne. 


\section{THE LATE NINETEENTH-CENTURY STONE FARMHOUSES OF JOHN THOMPSON CRELLIN ${ }^{1}$}

KAREN ARMSTRONG is a graduate of the School

of Fashion at Ryerson Institute of Technology

(Ryerson University). An independent scholar,

her interests are centred on nineteenth-century buildings in Ontario.

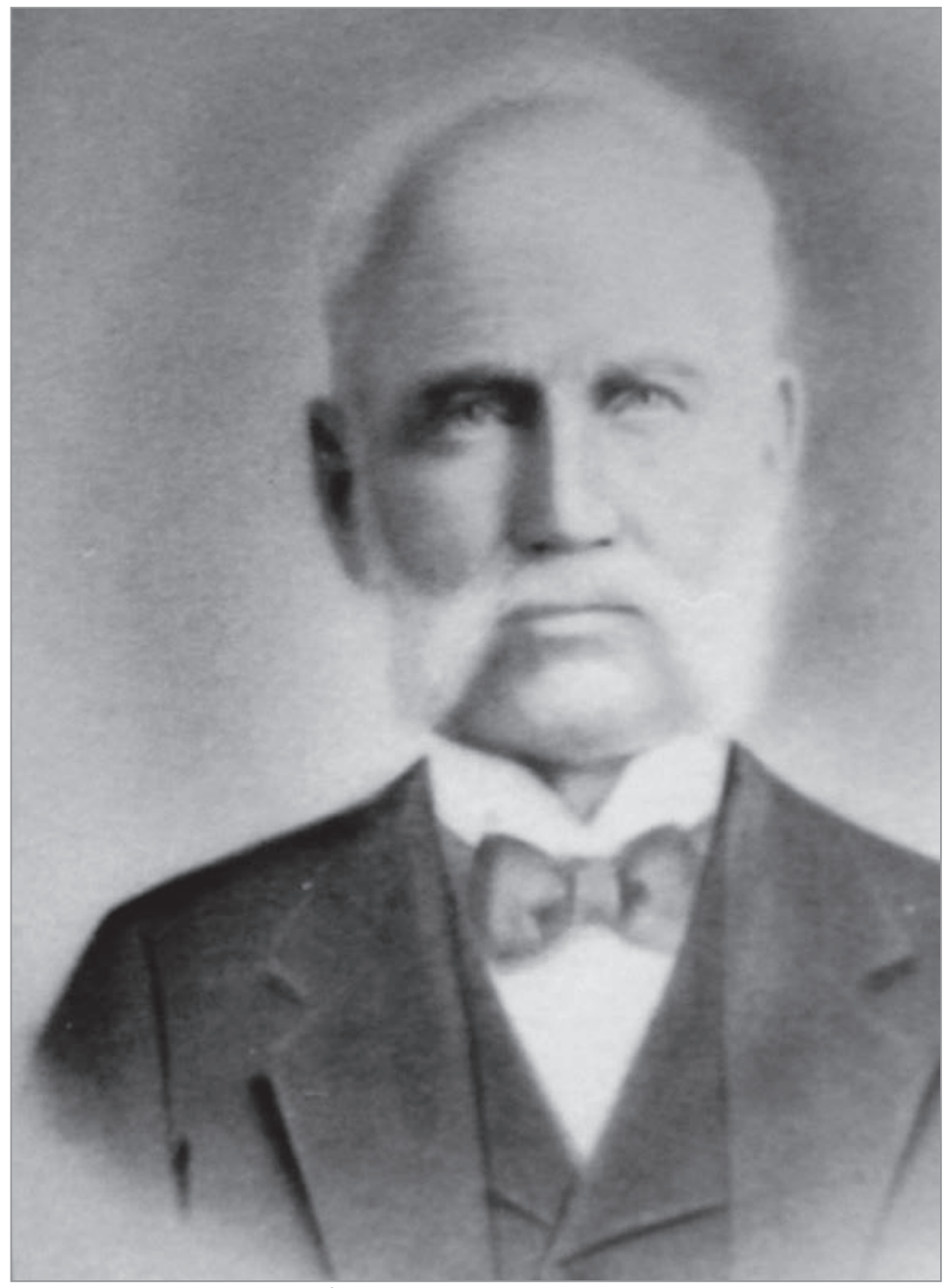

FIG. 1. JOHN THOMPSON CRELLIN. | PHOTO: SPECIAL THANKS TO ALICE CRELIN INGLE.

\author{
Karen Elisabeth \\ ARMSTRONG ${ }^{2}$
}

$T^{1}$ he abundant published materials that offered design inspiration and aesthetic advice in England and the United States from the late eighteenth century onward were a major influence on nineteenth-century architecture. Recent scholarship examining house patterns published in The Canada Farmer between 1864 and 1876 has revealed the power of print media to shape an array of relatively modest dwellings in towns and cities in Southern Ontario. This article will show the impact of print media on rural housing in Oxford County and the role of an unknown English immigrant stonemason, John Thompson Crellin, in the translation of five designs published by James Avon Smith in The Canada Farmer into twelve stone farmhouses. Working between 1870 and 1891, Crellin developed a unique, instantly recognizable colour pattern on his façades derived from multi-coloured fieldstones sourced from farmers' fields. The widely disseminated ideas of the British theorist John Ruskin seem to be reflected in these farmhouses, particularly in the ways Crellin's wall construction reveals the inherent qualities of quarry-faced masonry.

A close examination of Crellin's twelve stone farmhouses shows how, over time, the stonemason and his clients evolved away from the strict implementation of the house designs from The Canada Farmer toward a new vision for the planning of their farmhouses. Far from being remote and isolated, the houses are evidence that the farmers were connected to the mainstream through new developments in transportation, technology, and aesthetic thought emanating from 
abroad and visible in sophisticated urban centres like London in Ontario. What makes this research especially potent is that by 1891 in Crellin's last known building, his patron David Lawrence appears to have believed that he invented something new, publishing an illustrated description of his house in a major American farm journal. Lawrence's foray into publishing illustrates that these farmers were keenly aware of their ties to the world and that they too could participate in the international economy of design ideas.

\section{MODELS FOR INSPIRATION: JAMES AVON SMITH AND THE CANADA FARMER}

\footnotetext{
"I desire my reader to observe carefully how much of his pleasure in building is derived, or should be derived, from admiration of the intellect of men whose names he knows not."

-Ruskin, The Stones of Venice. ${ }^{3}$
}

In 1864, The Globe newspaper in Toronto began publishing The Canada Farmer, a biweekly journal. It included a column titled "Rural Architecture" in many of its issues written by the prolific Torontobased architect James Avon Smith [18321918]. His ideas were up-to-date and he realized that through print media he could provide readers with construction advice and helpful suggestions to guide their thinking and aesthetic choices. Over the course of roughly ten years he published designs for approximately eighteen houses, two churches, four schoolhouses, an octagonal exhibition building, and buildings for a farm of one hundred acres. Smith's articles published in The Canada Farmer were the only Canadian source that disseminated modern design ideas to a Canadian readership until The Canadian Architect and Builder appeared in 1888. The main competition was American pattern book publishing, which increased over the years; Canadians read and ordered house patterns from them. According to Harold Kalman, "Canadian architects and builders read those pattern books which must have had an immense impact on their designs, but few of the associated houses have been identified."4

Smith read American pattern book literature citing Andrew Jackson Downing [1815-1852] and Lewis Falley Allen [18001890] in some of his house descriptions. Smith agreed with Downing's statement that "a good house is a powerful means of civilization ..." In the same article Smith borrowed a house plan from Downing and quoted his advice: "The house should look like a farmhouse, expressing the beauty of a farmer's life ..." In another description, he quoted Allen who wrote: "The house should present an agreeable aspect from all viewing points ..." Smith's articles also reveal that he was aware of larger international trends. Another major source was the work of the prominent British theorist John Ruskin [1819-1900]. As Henry-Russell Hitchcock observed, "Ruskin had almost from the original publication of his Seven Lamps of Architecture in 1849 more readers beyond the seas than at home." ${ }^{8}$ Although he does not name Ruskin, when one reads Smith's articles, Ruskin's ideas are apparent. ${ }^{9}$ Like Ruskin, Smith prized the qualities of stone, saying: "There is . . an air of stability and durability about a stone structure; age, so far from being destructive to it, only increases its beauty . . ."10

In an article published in 1869, Smith stated that "many of the designs from The Canada Farmer have been used as models all over the province."11 Smith's first three elevations are discussed by Jessica Mace in her 2013 article examining vernacular nineteenth-century Gothic Revival houses in Southern Ontario. Mace has shown that Smith is responsible for more houses in Ontario than any other nineteenth-century architect, stating that his plans were "meant to be a basic and versatile prototype rather than a direct model."12 In his examination of nineteenth-century housing in downtown Toronto, Scott Weir outlined the history and development of the bay-and-gable house style from its origins in eighteenthcentury England. Bay-and-gable houses appeared in Toronto from around 1870 to $1900 . .^{13}$ Smith wrote in 1867: "A home similar to the above [Smith's drawing] was erected in Toronto in $1863 . .^{14} \mathrm{He}$ illustrated that article with his flat façade story-and-a-half "Country House." It has an interior plan almost identical to the house plans illustrated in Weir's article. ${ }^{15}$ The success of Smith's published designs in The Canada Farmer was due to the clarity and simplicity of his plans. They were easily adapted to stylistic changes, tightly packed building sites, and city restrictions. Best of all, the designs were available to farmers and builders for a dollar a year or eight cents a copy from the presses at the Globe newspaper.

\section{A RURAL "BUILDER AND CONTRACTOR": JOHN THOMPSON CRELLINI16}

\footnotetext{
"In no art is there closer connection between our delight in the work and our admiration of the workman's mind than in architecture, and yet we rarely ask for a builder's name."

-Ruskin, The Stones of Venice. ${ }^{17}$
}

As the recent articles by Mace and Weir suggest, the implementation of Smith's designs fell to the many anonymous craftsmen and clients throughout Ontario who found inspiration in The Canada Farmer. This article will focus on a group of twelve modest but distinctive farmhouses built by one craftsman-John Thompson Crellin-and the 
clientele of farmers who hired him and contributed to translating architectural diagrams into farmhouses reflecting their way of life. Crellin's stonemasonry made Smith's designs into a physical reality in the Ontario landscape. The farmhouses reveal the striking yet hitherto little-examined potential for the humble craftsman to realize the larger aesthetic goals advocated by prominent theorists such as Ruskin who inspired sophisticated urban architects like Smith. Instead of hiring an architect, Crellin's clients paid the stonemason to provide them with the good taste and sophistication that Smith hoped would transform the countryside. With their distinctive masonry, patterning, and colour, the houses examined in this article are in essence signed "John Thompson Crellin."

Crellin was born in Ulverston, Cumbria, England, in 1837 (fig. 1). ${ }^{18}$ The Crellin family originally came from the Isle of Man; building in stone was a family speciality. ${ }^{19}$ The single critical event in Crellin's career was his decision to immigrate to Oxford County, Ontario, sometime between 1865 and $1869 .{ }^{20} \mathrm{An}$ informal family history called "Branches" tells that the Crellin and McComb families were friends in England when the McCombs immigrated to Oxford County in 1850. Crellin married Elizabeth McComb in 1870 and built his first farmhouse for her family. At the time of his marriage, Crellin bought eight acres of land, two kilometres north of Kintore on what is now Highway 119, and began building the picturesque stone house that became the Crellin home.

When Crellin immigrated to Canada, the impact of James Avon Smith's farmhouse designs was already being felt across Southern Ontario. The Canada Farmer had been in production for a few years and Canada had just become a nation with Confederation in 1867 . The Canadian Bureau of Agriculture was established in 1852 and the farm economy of Southwestern Ontario changed so radically, that by 1867 there were two hundred cheese factories in the province. In 1873, butter factories were introduced as well. ${ }^{21}$ In the context of Oxford County, one of the most discernible results of agricultural policies was the change from wheat to dairy farming. As a consequence, farmers were making money and the visual aspect of their farms changed accordingly. Shanties and wood frame buildings were replaced or supplemented by picturesque masonry houses that by their very nature were expensive. In an article written for the November 15, 1872, issue of The Canada Farmer, an author visiting Southwestern Ontario farms stated:

Formerly, on my last visit, these men, in very many cases, had "poor conveyances, or none, poor horse teams, and often only oxen, almost always there were old log houses," and old log barns and, with few exceptions, very poor fences. Now the case is most materially altered for the better, and I am pleased to record, that in a vast number of cases these men have good, and even handsome buggies, and occasionally good double seated wagons, drawn by fine horses, with good substantial, and even ornamental harness. These have replaced the old teams and the log barns are gradually ceasing to exist as such, but are degraded into cattle sheds. Good substantial frame barns are now seen in every direction. There are still occasionally seen some old log houses that are inhabited, a memento of former "raisings" and beginning in the bush. But, very often these stand close by good frame or brick edifices, well and comfortably furnished [sic]. ${ }^{22}$

Crellin thus immigrated to a rural context transitioning toward more lucrative and stable farm production. It was there that he would make his career building homes for a prosperous clientele. The twelve houses that can be firmly attributed to him are situated in the northwest quadrant of Oxford County on dairy farms scattered through the countryside near Thamesford, Kintore, Medina, Lakeside, Wildwood Park, Embro, and Golspie, all sites located north and west of Woodstock, the county seat.

This article is based on a close analysis of these twelve buildings, which can be dated to the period between 1870 and 1891. One source of inspiration was very likely five drawings published by Smith in The Canada Farmer. Each of the designs will be listed in the order published by Smith along with the twelve Crellin farmhouses and the date of each house if known. The first design is the "Suburban Villa or Farm House"23 that appeared in The Canada Farmer in 1864 (fig. 2.1), also known as the "L," "bent," or the "cross wing house. ${ }^{24}$ The six houses by Crellin based on this model are: the Duncan house, 1872 (fig. 3); the Crellin house, c. 1878 (fig. 4); the Clarke house, 1882 (fig. 5); the Towle house (a two-story version), c. 1885 (fig. 6); the Lawrence (fig. 7) and the Alexander Sutherland houses, both from 1891 (fig. 8). The second design by Smith that inspired Crellin's clients was a one-and-a-half-story "Cheap Farm House," published in 1864 (fig. 2.2), also widely known as the "Ontario Cottage." 25 The three farmhouses that Crellin built using this model were the McComb house, c. 1870 (fig. 9); the Robert Sutherland (fig. 10) and the McCorquodale (fig. 11) houses, both undated. The third plan used by Crellin is "A Two-Story Farm House" of 1865 (fig. 2.3), characterized by a centre front two-story projection edged in quoins, with a window above the front door. ${ }^{26}$ The William Reid house is the one instance of this plan adapted by Crellin, with the date "1885" carved 


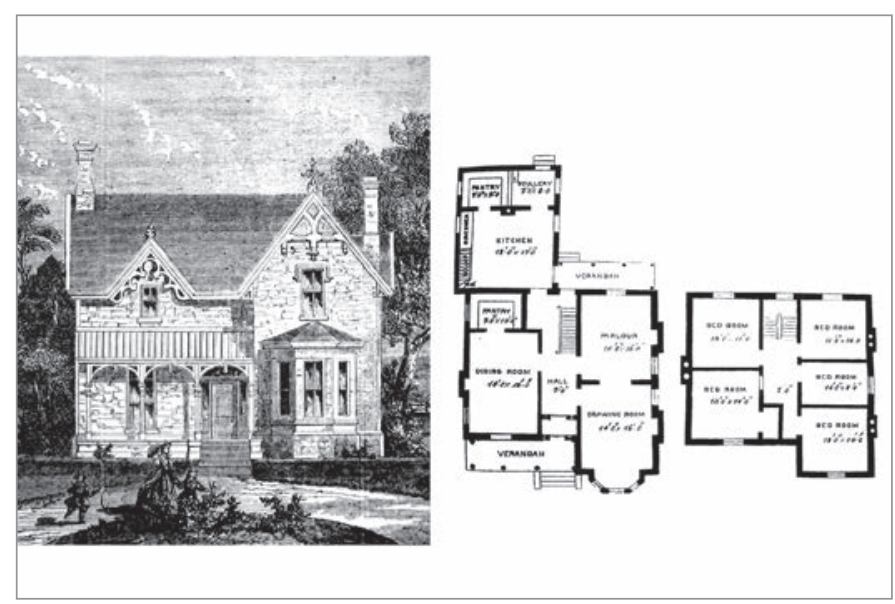

FIG. 2.1. "SUBURBAN VILLA OR FARM HOUSE," THE CANADA FARMER, 1864,

VOL. 1, NO. 9, P. 132. | TORONTO REFERENCE LIBRARY, SPECIAL COLLECTIONS DEPARTMENT.

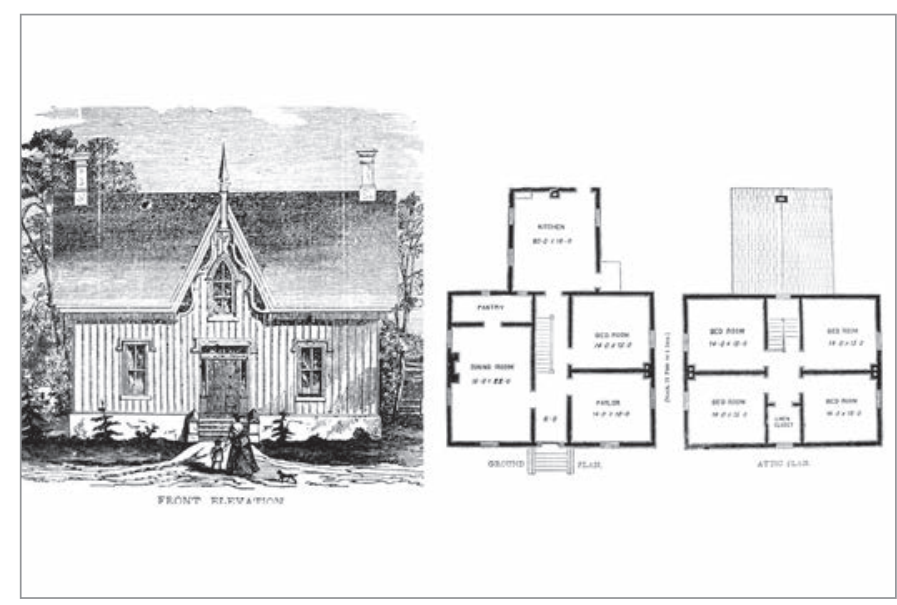

FIG. 2.2. "A CHEAP FARMHOUSE," THE CANADA FARMER, 1864,

VOL. 1, NO. 22, P. 340. | TORONTO REFERENCE LBRARY, SPECIAL COLLECTIONS DEPARTMENT.

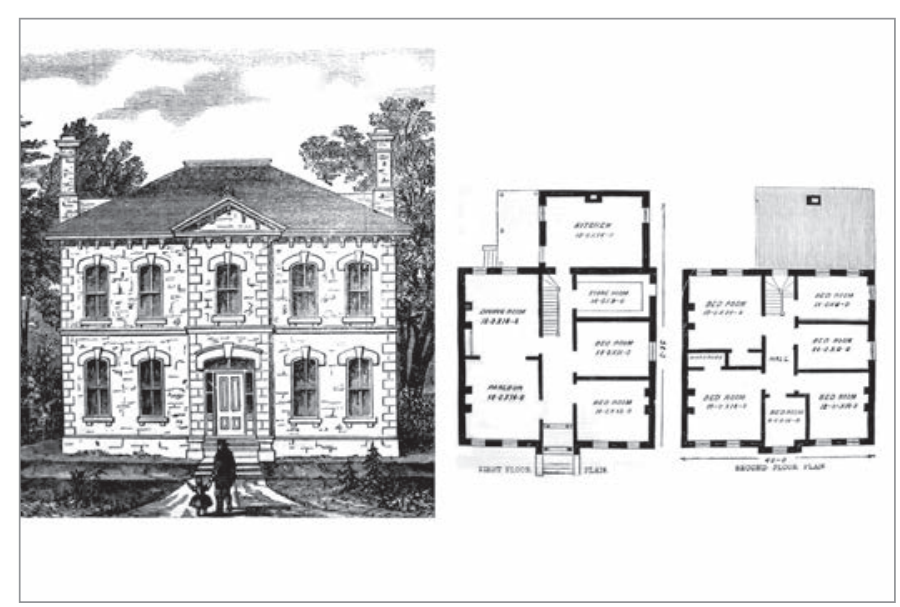

FIG. 2.3. "A TWO-STORY FARMHOUSE," THE CANADA FARMER, 1865,

VOL. 2, NO. 8, P. 116-117. | TORONTO REFERENCE LBRARY, SPECIAL COLLECTIONS DEPARTMENT.

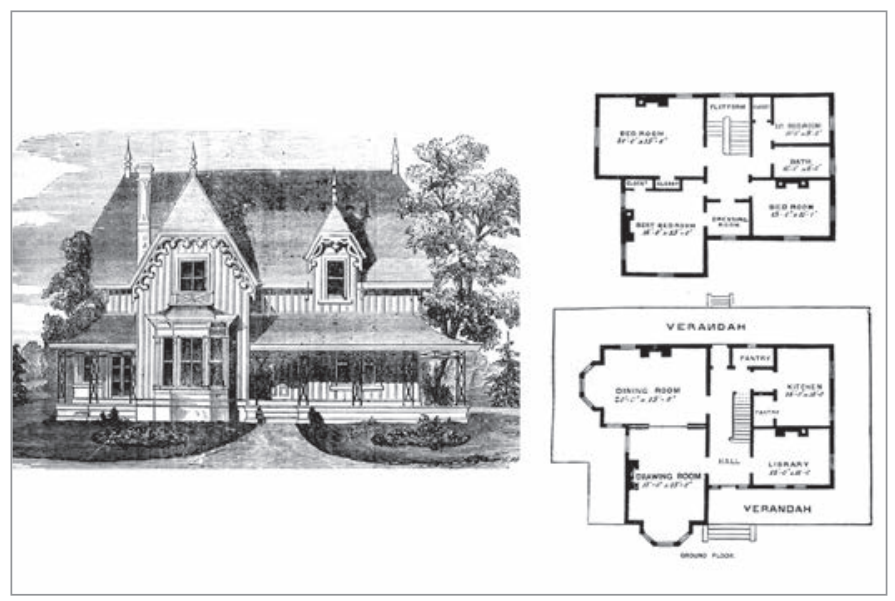

FIG. 2.4. "A CHEAP COUNTRY HOUSE," THE CANADA FARMER, 1868,

VOL. 5, NO. 16, P. 244-245. | TORONTO REFERENCE LBRARY, SPECIAL COLLECTIONS DEPARTMENT.

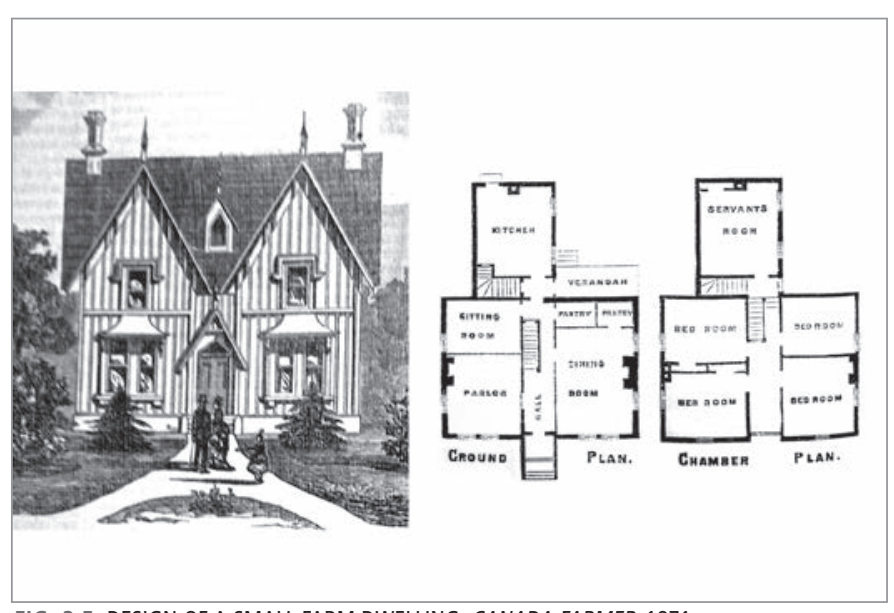

FIG. 2.5. DESIGN OF A SMALL FARM DWELLING, CANADA FARMER, 1871,

VOL. 3, NO. 1, P. 16 | TORONTO REFERENCE LIBRARY, SPECIAL COLLECTIONS DEPARTMENT.

into the façade (fig. 12). The fourth model is the story-and-ahalf "Cheap Country House" of 1868 (fig. 2.4). ${ }^{27}$ This farmhouse has a centre gable with a wing on either side. The Seaton house inspired by this design has a cartouche in the front gable with the inscription: "Erected in 1873 by Francis German and John Seaton" (fig. 13). The final house plan used by Crellin is Smith's "Design of a Small Farm Dwelling," 28 a symmetrical house with two equal-sized front gables, published in 1871 and directly inspired by one of Downing's designs (fig. 2.5). ${ }^{29}$ The Clifford house completed in 1877 follows this plan (fig. 14). In addition to identifying these farmhouses, my research reveals a complex process by which the craftsman and his clients contributed to transforming those designs into highly distinctive structures that incorporated not only up-to-date planning and technology, 
but also a sophisticated visual aesthetic derived from the very soil upon which these houses were built.

\section{THE STONEMASON'S AESTHETIC: ABERDEEN BOND AND CONSTRUCTED POLYCHROME}

"Of the many broad divisions under which architecture may be considered, none appear to me more significant than that into buildings whose interest is in their walls ...."

-Ruskin, The Lamp of Power. ${ }^{30}$

In all his houses, Crellin used a distinctive pattern of stone construction I will refer to as "Aberdeen Bond." This masonry style began to evolve at the end of the eighteenth century in and around Aberdeen, Scotland. Small stones called "pinnings" or "cherry caulking" 31 were used to fill the gaps between large blocks of granite (fig. 15). In all of Crellin's houses, regularly cut "snecks" (three equal-sized small squared stones) were stacked vertically between larger rectangular blocks (fig. 16). ${ }^{32}$ On the front façades of Crellin's houses, each course begins at the corner with a white limestone quoin, followed by three small square snecks of black basalt over pink granite over black basalt stacked to the height of the quoin. The stack of snecks is followed by a single large block of quarry-faced stone, which is followed in turn by the three snecks, and so on across the façade. The larger stones vary in colour, suggesting that each was selected at the moment of construction from piles of stones collected from the farm fields and transported by horses and a stone-boat to the building site. The quarry-faced or "rocky" aesthetic of Crellin's façades speaks of the high level of skill required for their construction, fulfilling Ruskin's contention that it is "a folly, in most cases, to cast away the labour necessary to smooth it; it is wiser to make the design granitic itself and to leave the blocks rudely squared ... There is also a magnificence in the natural cleavage of stone ..." ${ }^{33}$ Contrasting with these rough, fieldstone surfaces, all the quoins, sills, lintels, and voussoirs of Crellin's houses are articulated with white St. Marys limestone. The overall colour palette of each house is thus created by contrasting uniform white lines above and below windows, and along the corners with an infill of subtly varied polychromatic fieldstones. Crellin's Aberdeen Bond farmhouses give the impression of a definite overall pattern that from a distance looks like the weave of a textile or a pattern in tile.

Each of the four façades of most of the Crellin-built farmhouses uses different masonry patterning, indicating a clear hierarchy based on prominence and visibility. In nine cases-Duncan, 1872 (fig. 3), Seaton, 1873 (fig. 13), Clifford, 1877 (fig. 14), Crellin, 1878 (fig. 4), McCorquodale (fig. 11), Clarke, 1882 (fig. 5), Towle, c. 1885 (fig. 6), Lawrence, 1891 (fig. 7), and Alexander Sutherland, 1891 (fig. 8)-a secondary façade is made up of even courses of masonry beginning at each quoin with stacks of two snecks in random colours rather than three (fig. 17). In all these cases, this secondary façade faces a driveway. The wall of the house opposite the driveway side is made up of courses of squared blocks of fieldstone of similar size with no snecks, while the back wall of the kitchen wing is rubble. If the kitchen wing was not built by Crellin, the back of the house is built of rubble as in the case of four houses: McComb, 1870 (fig. 9), Seaton, 1873 (fig. 13), Robert Sutherland (fig. 10), and McCorquodale (fig. 11) (the date of the latter two houses is unknown).

In one instance-the McComb house which was likely Crellin's first-the north secondary façade follows exactly the same patterning as the east front façade with stacks of three snecks between larger blocks, suggesting that Crellin was new to the use of Aberdeen Bond. He arrived at the colour combination of black over pink over black snecks at the second-floor level of both façades of the McComb house after many experiments using coloured snecks in various combinations, on the east and north walls facing the driveway that encircled the house. The south wall of the house on this driveway is made up of courses of quarry-faced blocks alternating with stacks of two randomly coloured snecks, such that three sides of the McComb house are built in Aberdeen Bond, two of which use courses containing three snecks and one with courses of two stacked snecks.

In the two remaining instances of Crellin's work-the Robert Sutherland house (fig. 10) and the Reid house, 1885 (fig. 12) -no special secondary façade is included. The William Reid house has snecks in reverse order-pink over black over pink. In both houses, the two sidewalls perpendicular to the front façade consist of regular courses of large blocks with no snecks. The striking masonry of Crellin's houses seems to be the built realization of Ruskin's dictum that "the smaller the building the more necessary that the masonry be bold and vice versa." ${ }^{34}$ We can never know what exactly this extraordinary stonemason was reading, but in these farmhouses we find astonishing parallels between his work and the writings of Ruskin on colour, pattern, and masonry.

In Crellin's architecture, Aberdeen Bond was a vehicle for constructed polychrome, a key characteristic of late nineteenth-century architecture in the United Kingdom and North America. Ruskin's assertion that "the true colours of architecture are those of natural stone" 35 is especially relevant 


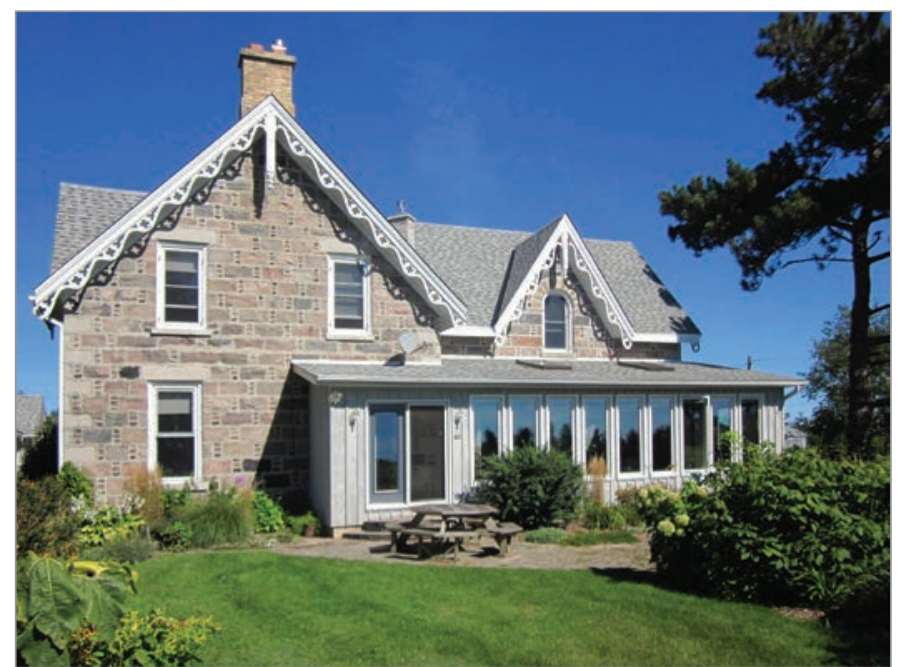

FIG. 3. DUNCAN HOUSE, 29 ${ }^{\text {TH }}$ LINE, NO. 7006, NEAR HARRINGTON, OXFORD COUNTY. | KAREN E. ARMSTRONG.

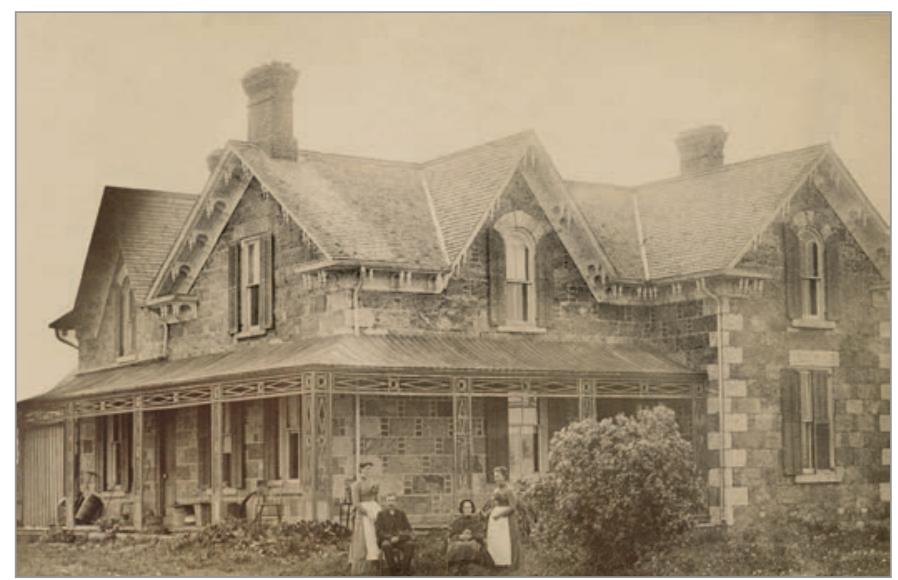

FIG. 5. CLARKE HOUSE, $1882,45^{\text {TH }}$ LINE, NO. 5753, NORTH OF GOLSPIE, OXFORD COUNTY. | SPECIAL THANKS TO STEVE MACDONALD.

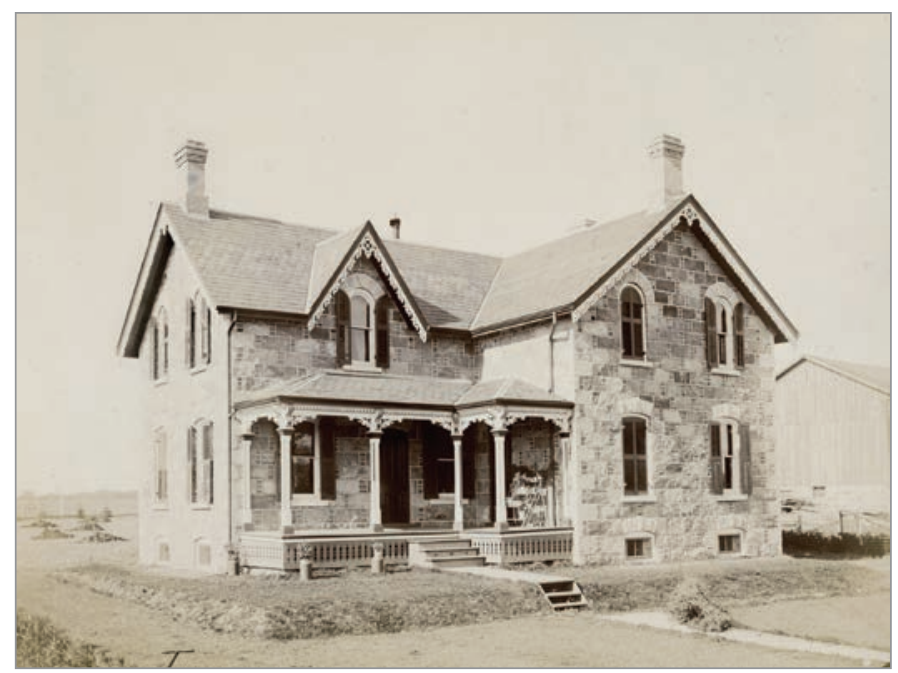

FIG. 7. LAWRENCE HOUSE, 1891, 209 ALLEN ST., THAMESFORD, OXFORD COUNTY. | AMERICAN AGRICULTURIST, 1894.

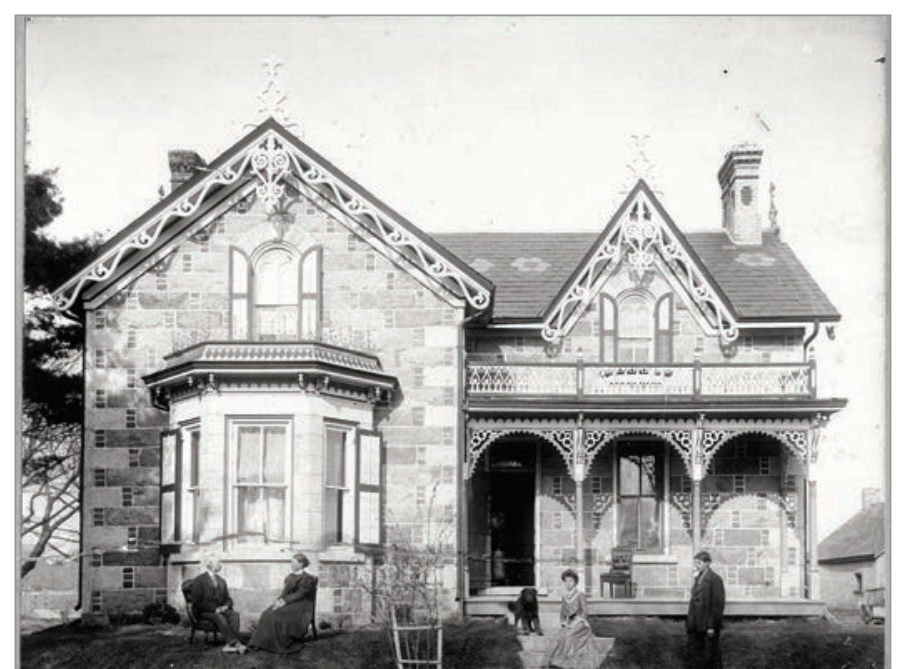

FIG. 4. CRELLIN HOUSE, 19TH LINE, NO. 6150 (HIGHWAY 119), NORTH OF KINTORE, OXFORD COUNTY. | C. 1903 CARTER AND ISSACS OF ST MARYS. SPECIAL THANKS TO KRISTA CRELIIN.

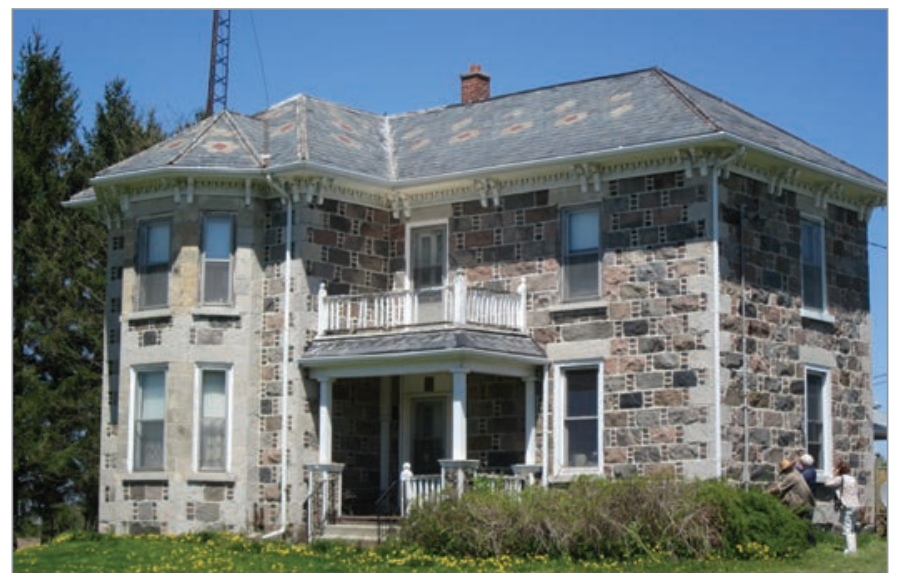

FIG. 6. TOWLE HOUSE, 19 $9^{\text {TH }}$ LINE, NO. 6432 (HIGHWAY 119), MEDINA, OXFORD COUNTY. | KAREN E. ARMSTRONG.

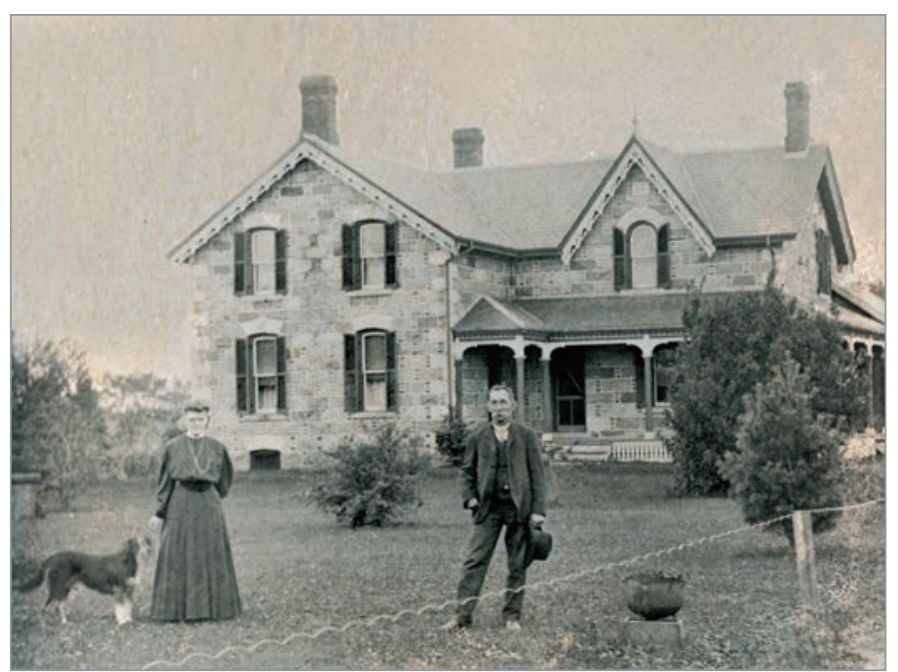

FIG. 8. ALEXANDER SUTHERLAND HOUSE, 1891, ROAD 74, NO. 4358, GOLSPIE, OXFORD COUNTY. | SPECIAL THANKS TO KEN JUDGE. 


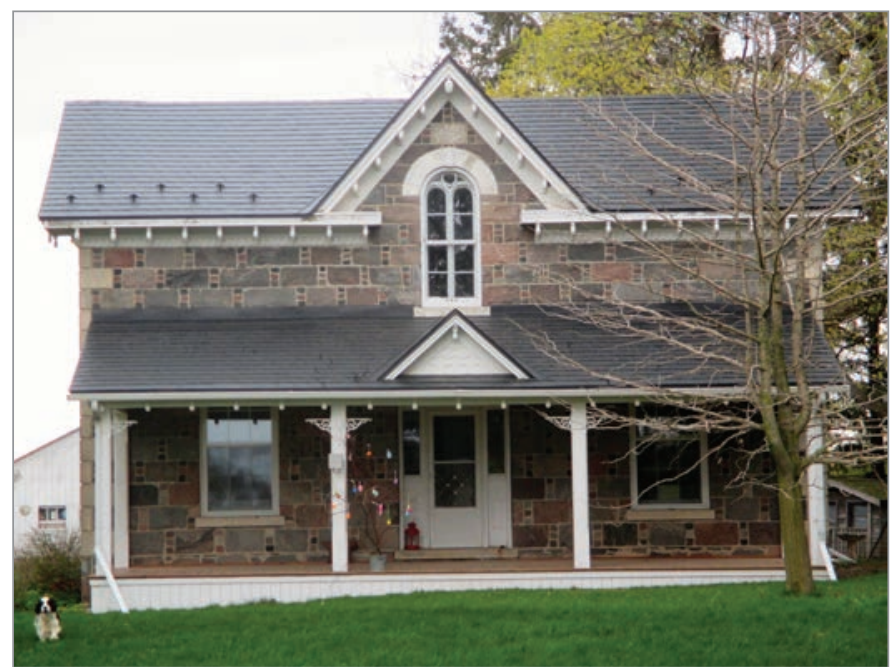

FIG. 9. MCCOMB HOUSE, 33RD LINE, NO. 6603, NEAR HARRINGTON, OXFORD COUNTY. | KAREN E. ARMSTRONG.

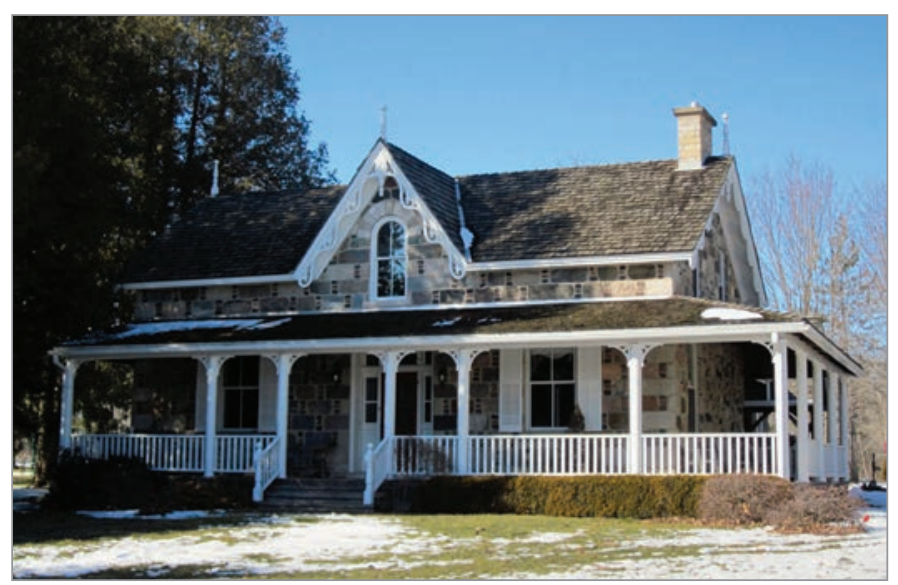

FIG. 10. ROBERT SUTHERLAND HOUSE, ROAD 74, NO. 4357, GOLSPIE, OXFORD COUNTY. | KAREN E. ARMSTRONG.

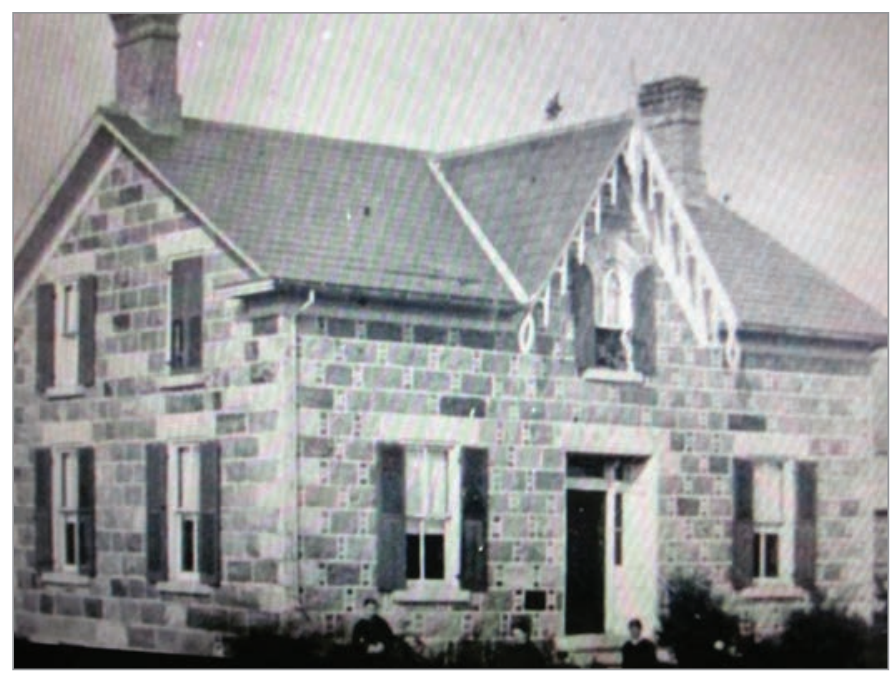

FIG.11. MCCORQUODALE HOUSE, 29'H LINE, NO. 6565, NEAR HARRINGTON, OXFORD COUNTY. | UNDATED EARLY PHOTOGRAPH BY JOYCE GROVES.

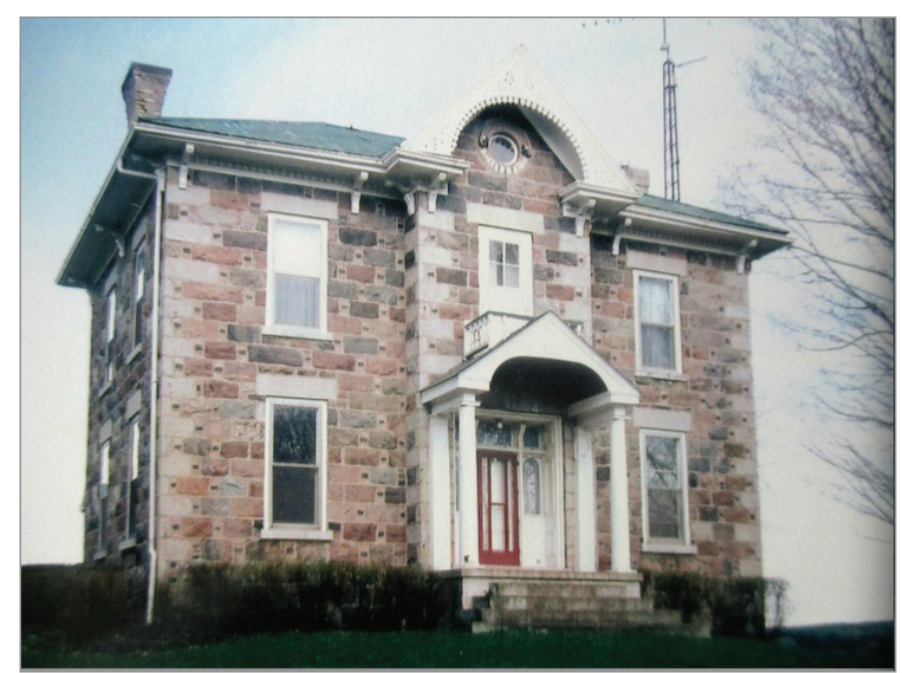

FIG. 12. REID HOUSE, 37 $7^{\text {TH }}$ LINE, NO. 6642 (HIGHWAY 6), NORTH OF EMBRO, OXFORD COUNTY. | KAREN E. ARMSTRONG.

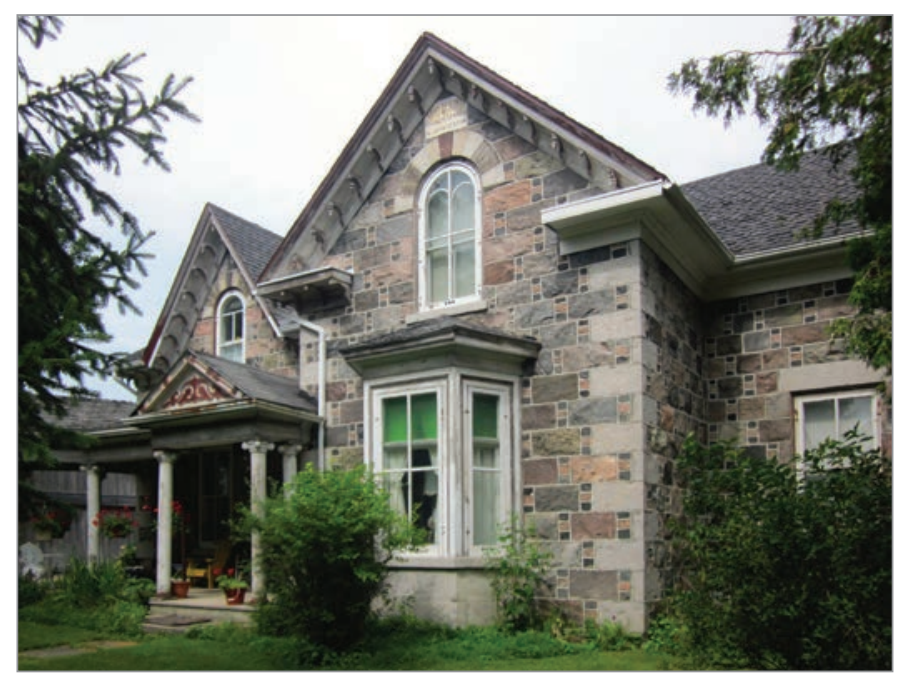

FIG. 13. SEATON HOUSE, 25 $5^{\text {TH }}$ LINE, NO. 6594, LAKESIDE, OXFORD COUNTY. | KAREN E. ARMSTRONG.

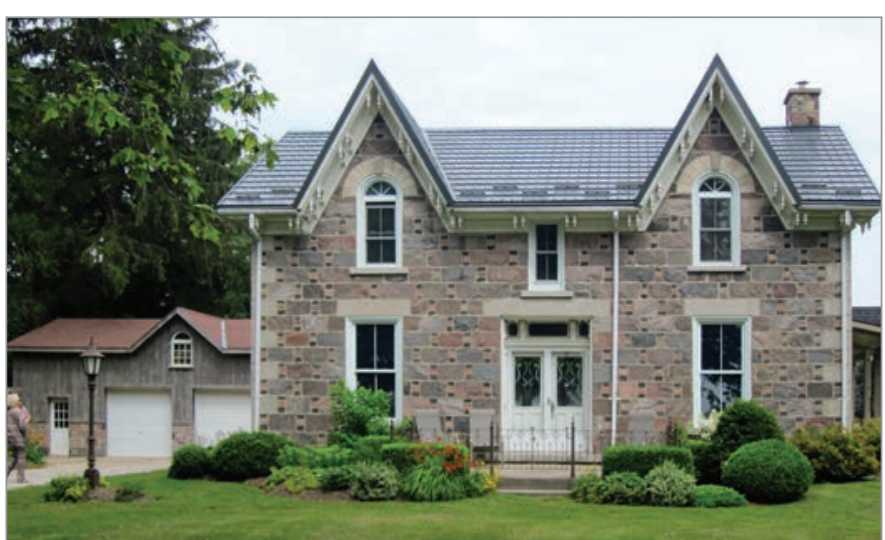

FIG. 14. CLIFFORD HOUSE, 31 ${ }^{\text {ST }}$ LINE, NO. 7144, WILDWOOD PARK, OXFORD COUNTY. | KAREN E. ARMSTRONG. 


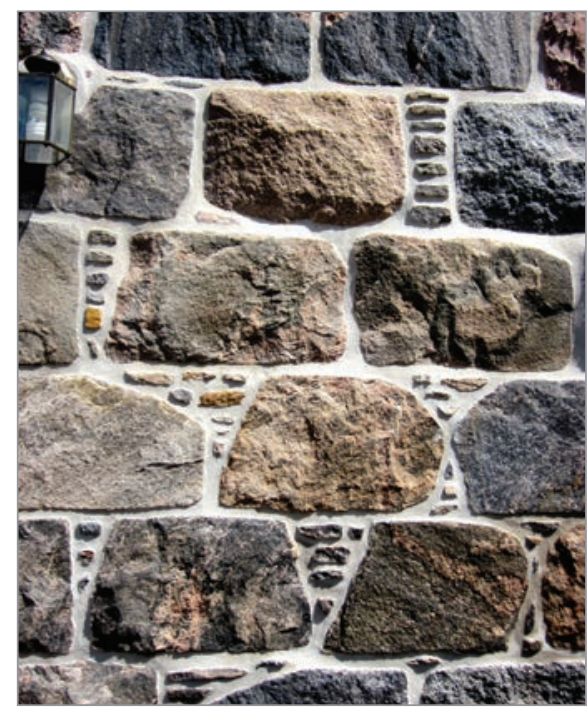

FIG. 15. PINNINGS FILLING GAPS BETWEEN STONE BLOCKS BY AN ANONYMOUS CRAFTSMAN, $35^{\text {TH }}$ LINE, NO 6432, NEAR EMBRO, OXFORD COUNTY. | KAREN E. ARMSTRONG.

when looking at Crellin's houses, as was Ruskin's belief that the best design resulted from "chequered patterns and in general such ornaments as common workmen can execute." ${ }^{36}$ William Butterfield [1814-1900] ${ }^{37}$ in England and Henry Hobson Richardson [1838-1886] ${ }^{38}$ in the United States were among the many architects who read and were inspired by Ruskin's concepts, the former originating the use of contrasted coloured brick, the latter experimenting with patterns created by combinations of different coloured stones. Butterfield and Richardson were working at the same time as Crellin and their ideas were known through publications, which included photographs of their buildings. All participated in a larger visual culture of architecture that sought ornament and pattern in the qualities of natural materials. In this remarkable instance, Crellin brings to the building site not just competence, skill, and business acumen, but also a true aesthetic sensibility revealed through constructed polychrome. Aberdeen Bond was used by other stonemasons throughout Southern Ontario, but none of those buildings use a regularized colour pattern.

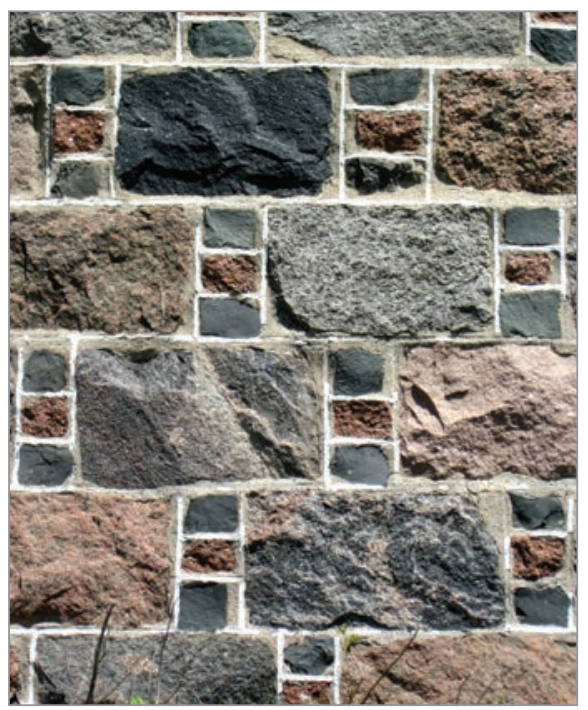

FIG. 16. CRELLIN'S ABERDEEN BOND STYLE MASONRY, WITH 3 SNECKS, MCCORQUODALE HOUSE, I 29 $9^{\text {th }}$ LINE, NO. 6565, NEAR HARRINGTON, OXFORD COUNTY. | KAREN E. ARMSTRONG.

It probably took Crellin and his crew of eight to thirteen men from early spring to late fall to complete the stonemasonry on a farmhouse. ${ }^{39}$ Crellin's main income came from building stone barn ${ }^{40}$ and house ${ }^{41}$ foundations along with stone walls surrounding properties and stone entrance pillars. During the last half of the nineteenth century, the culture of ornament and the desire for sophisticated, distinctive patterning in construction was such that if farmers only had a barn or house foundation built by Crellin, some paid extra to have the Aberdeen Bond style on the side of their buildings that faced the road (fig. 18). Farmers thus signalled to passers-by that they were aware of the latest trends in stone masonry and they could afford the best.

\section{FORM FOLLOWS FUNCTION AND FASHION: NEW TECHNOLOGIES, PLANNING, AND MATERIALS}

"Strong and frank - telling its own story at a glance ... it is neither mean nor meagre."

—Smith, The Canada Farmer. ${ }^{42}$

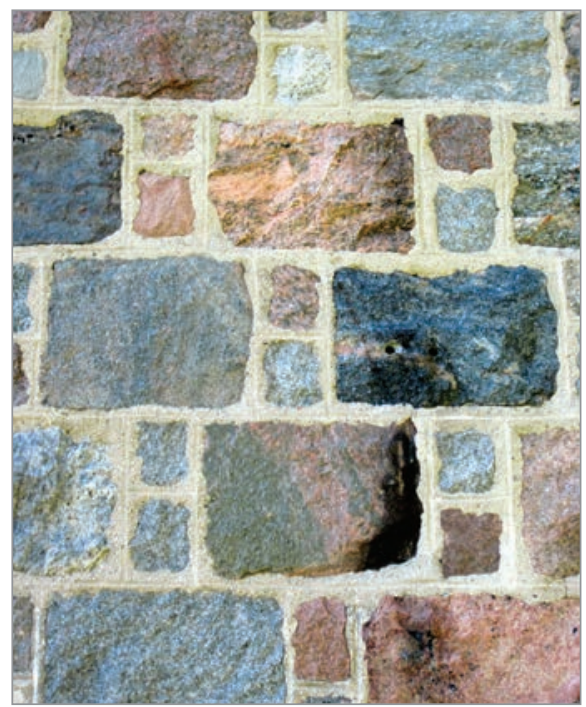

FIG. 17. CRELLIN'S ABERDEEN BOND STYLE MASONRY WITH 2 SNECKS, MCCOMB HOUSE, I 33RD LINE, NO. 6603, NEAR HARRINGTON, OXFORD COUNTY. | KAREN E. ARMSTRONG.
Crellin was a smart businessman whose well-to-do farmer clients were intent on showing they were modern. In their houses, they fused five designs (fig. 2) from The Canada Farmer and Crellin's masonry aesthetic with contemporary trends apparent in new buildings in nearby London. ${ }^{43}$ Just as Crellin transformed the exterior wall articulation of Smith's house designs, window shapes and roof detailing were updated as well, drawing on such notable examples, perhaps, as the new London Custom House (1870-1873) ${ }^{44}$ and the City Hospital $(1875)^{45}$ designed by William Robinson [1812-1894] in a restrained Second Empire style. New public and private architecture in other nearby centres such as Ingersoll, St. Marys, Stratford, and Woodstock no doubt also provided inspiration.

By 1870, when Crellin began building his first farmhouse, the Gothic Revival detailing apparent in some of Smith's designs had run its course: Crellin never resorted to a pointed Gothic window in any of his houses. Instead, he used rectangular "two over two" windows along with 


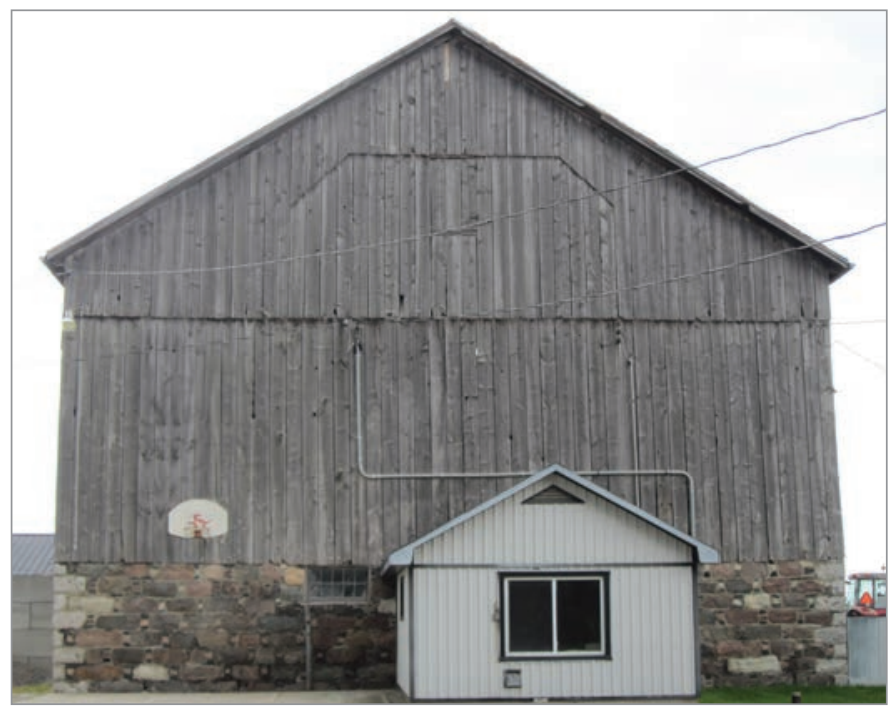

FIG. 18. CRELLIN'S ABERDEEN BOND BARN FOUNDATION, 13TH LINE, NO. 6332, OXFORD COUNTY. | KAREN E. ARMSTRONG.

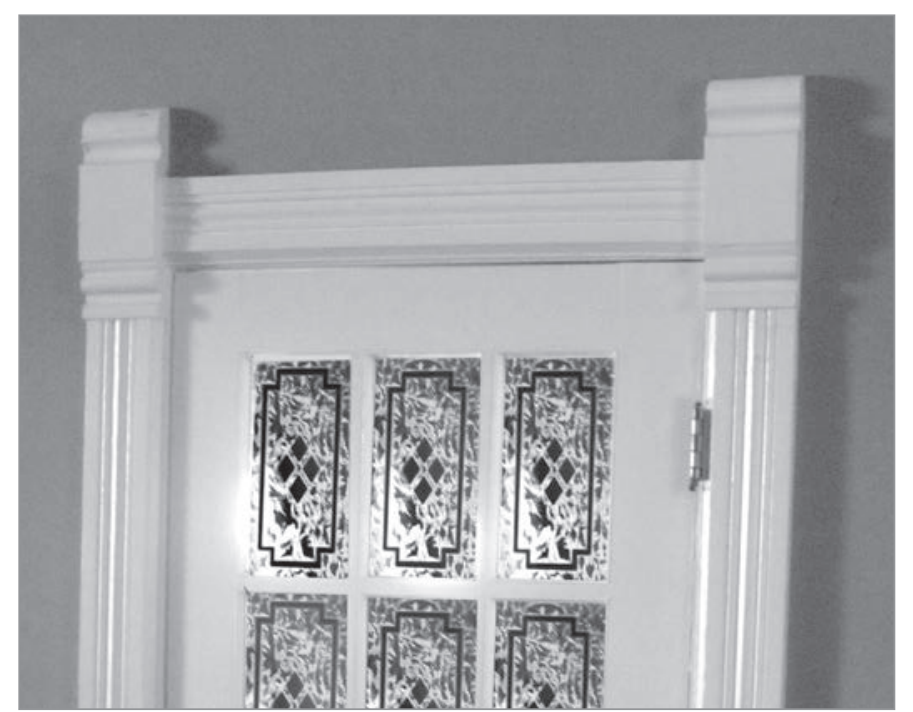

FIG. 19. ALEXANDER SUTHERLAND HOUSE, FRENCH DOORS, 1891, ROAD 74, NO. 4358 GOLSPIE, OXFORD COUNTY. | KAREN E. ARMSTRONG. segmental round arch windows until his last two houses in 1891, where he introduced the "one over one" and the flattened segmental arch window. Other trends current in London and elsewhere were the use of colourfully patterned slate roofs ${ }^{46}$ and decorative cast-iron cresting. ${ }^{47}$ Slate roofs were probably used on all Crellin-built houses and original cast-iron cresting can still be found on the bay window roof of Crellin's own house. Of the Crellin houses that still have their original slate roofs, the Towle House has a Second Empire "floral motif" while the Lawrence and Alexander Sutherland houses have a "fish scale" pattern. ${ }^{48}$ The veranda roofs of Crellin's houses varied in shape and materials. Some were flat, some were bell curved; some were likely roofed with tin, others with slate. The Lawrence veranda still retains its original hipped roof with a pink floral slate decoration. The stylistic effects of window and roof design in Crellin-built farmhouses were clearly important to his clients and referenced recent urban architecture in the immediate region, itself a reflection of international trends.
In addition to being an expert stonemason, his houses reveal that Crellin was also a skilled and imaginative carpenter. There seems to be nothing Crellin could not make and he made it all without electricity. He was the embodiment of Ruskin's dictum "to those who love architecture, the life and accent of the hand are everything . . ." 49 He crafted the decorative bargeboards, shutters, door and window frames, staircases, and interior panelling for all his houses. He also made furniture, games, and toys still valued by his descendants, including a built-in china cabinet in the dining room of his own house. In 1884 he joined the King Solomon Masonic Lodge in Thamesford ${ }^{50}$ and built a roll-top desk with a glass-fronted bookcase above, topped by a wide moulding featuring the Masonic symbol. Changes in technology meant that Crellin could use mass-produced items such as speciality lumber for interior door and window frames. Other factory-produced items found in Crellin house interiors are plaster ceiling cornices, mouldings, and medallions, which could be purchased through mail-order catalogues.
Crellin and his patrons were concerned that the exterior of their houses express the functional aspects of the interior spaces. Like the masonry patterning built from local stones, this emphasis on functional clarity seems to fulfil a contemporary dictum expressed in Smith's articles that "the house should suggest its own story at a glance ..." ${ }^{51}$ The kitchen extensions on the back of Crellin houses tell a story of the house as a working system, which included cast-iron cooking stoves, storage, pantries, sculleries, and usually stairs to the cellar and sometimes stairs to bedrooms above. ${ }^{52}$ There may have been an indoor kitchen sink and pump, however all evidence of a water supply has been lost. A major feature in Smith's designs, the kitchen extension was built onto the back of the houses. In some instances, existing houses on the property were moved and tacked onto the back of Crellin's new farmhouses, a kind of adaptive-reuse recalling an earlier, less affluent phase of a family's history.

As the kitchen extensions demonstrate, Crellin and his clients were attentive to 
technology and functional considerations. From Smith's designs to Crellin's houses, the evolution in heating systems is particularly obvious. In all his designs published in The Canada Farmer, Smith used fireplaces for heating. The only fireplace built into a Crellin house appears in the dining room of the Lawrence house. Crellin and his clients realized that fireplaces were not adequate during the cold Canadian winters, so before 1882 his houses were heated exclusively with castiron stoves. From the 1882 Clarke house onward, Crellin installed the new "free or hot air" furnaces in his cellars that burned wood or coal and relied on convection to distribute heat throughout the house. Such systems proved inadequate, so Crellin continued to include cast-iron heating stoves along with furnaces in his houses. None of these cast-iron stoves or furnaces remain, but an early interior photograph of the 1891 Lawrence house shows a parlour stove with a smoke pipe attached to the ceiling. ${ }^{53}$

\section{BUILDING A MODEL FARM} HOUSE: THE LAWRENCE HOUSE (1891]

"Every man has, at some time of his life, personal interest in architecture."

-Ruskin, The Stones of Venice. ${ }^{54}$

Detailed research carried out on all the Crellin houses, together with an array of surviving documents, photographs, and owner testimonials, suggest that his clients had a major role in the decision-making process before and during the construction of their farmhouses. Published designs in The Canada Farmer, local models, and new products all played a part in their thinking. Space does not permit a detailed account of all Crellin farmhouses; here, I will provide an analysis of the Lawrence house of 1891, which not only stands as the culmination of Crellin's building practice, but also reveals the exceptional role of one client, David Lawrence, in the design of his own house. The plan and elevation of Crellin's exact contemporary Alexander Sutherland house $\mathrm{e}^{55}$ is essentially a mirror copy of the Lawrence house, but the Sutherlands had their own ideas about convenience and planning. In the case of Lawrence, the client's published writings reveal the thought process behind the creation of his farmhouse, which appears to be part of a media-savvy strategy to popularize his design internationally as a model. If James Avon Smith addressed a national public through The Canada Farmer, Lawrence succeeded in presenting his house to an even wider, global audience.

Located nineteen kilometres apart, the Lawrence and Sutherland farmhouses can be dated by inscriptions carved on blocks of stone incorporated into each house front. The usual "rocky aesthetic" and Aberdeen Bond with three snecks on the front and two snecks on one side facing a driveway are present. Externally, the Lawrence and Sutherland houses resemble Smith's "Suburban Villa or Farmhouse" published in The Canada Farmer in $1864 .{ }^{56}$ As early photographs show, the projecting front is widened to incorporate two windows, eliminating the projecting bay in Smith's design. The flattened segmental arch and "one over one" windows made their only appearance on these last two houses. An exterior feature that remains intact is the original slate roof with a fish scale design on the front facing the road. The Lawrence house veranda still retains its original slate hipped roof with a pink floral design. The Sutherland veranda was similar but enclosed in stone sometime in the mid-twentieth century and the section on the driveway side was removed. Both the Sutherland and the Lawrence verandas are " $L$ " shaped (a first for Crellin) to accommodate the front door that is located on the side wall of the projecting front or the short end of the "L." Unlike Smith's 1864 design, where one entered the house into a centre hall, one had two choices from the veranda in the Lawrence house. Either one walked directly into the large dining room that occupies the centre of the main floor, or entered into the staircase hall. In the Sutherland house there was the choice of entry from the veranda into the library or the staircase hall.

Both Lawrence and Sutherland appear to have wanted to express their Scottish origins by incorporating the Cross of St. Andrew (the patron Saint of Scotland) into the decor of their houses. In the Lawrence house, this motif is found at the peak of the bargeboards of the two gables on the front façade facing east and in the bargeboards of the secondary façade facing south. In the Sutherland house, the Cross of St. Andrew appears in ornamental frosted glass windows of three interior French doors (fig. 19). If this glass was created in 1891 at the same moment as the house, the only local art glass manufacturer was R. Lewis in London, who had no competition until the late 1890s when Hobbs Hardware set up a plant to manufacture art glass. ${ }^{57}$ In the construction photo of the Sutherland house (fig. 20), Lawrence and Sutherland are shown in a moment of Scottish solidarity, each clasping the other's forearm with one hand. Lawrence holds a roll of paper in his right hand and Sutherland appears to be gesturing to both of them with his left hand, saying: "We Scots worked together on the design of my house."

Bathroom technology seems to have had difficulty making in-roads in rural areas. ${ }^{58}$ Apparently, Crellin installed no bathrooms before the Lawrence and Sutherland houses. In the five house designs by Smith 


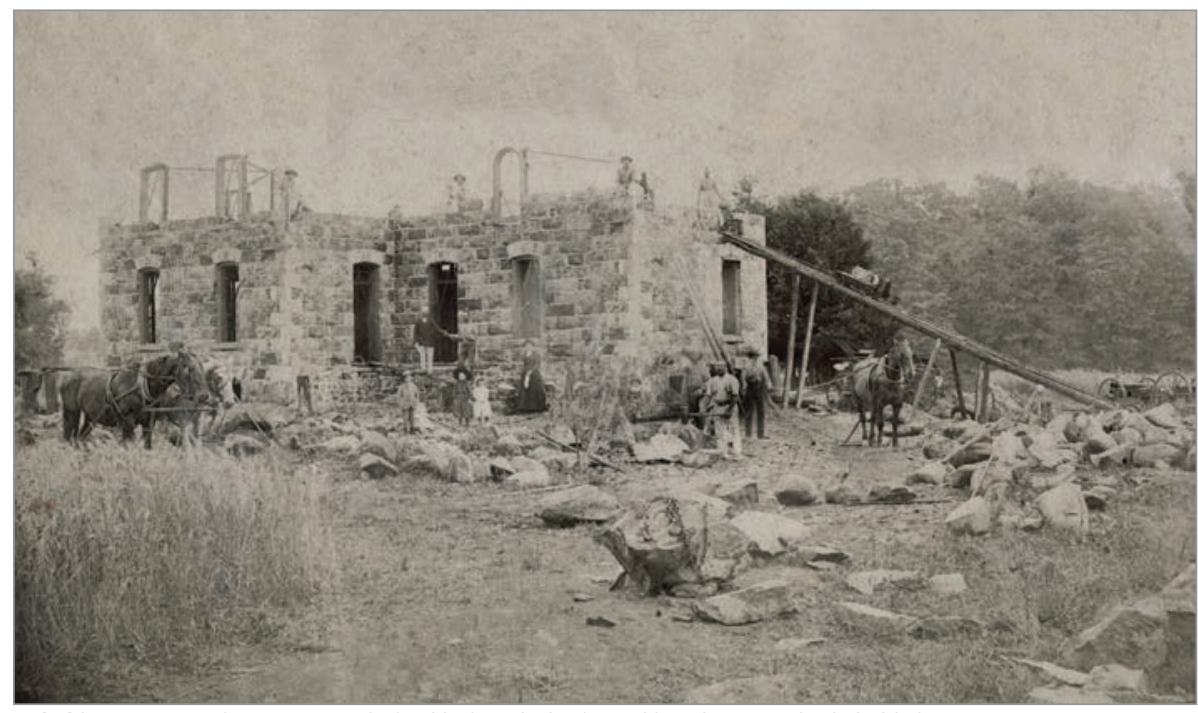

FIG. 20. ALEXANDER SUTHERLAND HOUSE, CONSTRUCTION SITE, 1891, ROAD 74, NO. 4358, GOLSPIE, OXFORD COUNTY. | SPECIAL THANKS TO KEN JUDGE.

that appear to have inspired Crellin and his clients, only one incorporated a bathroom. ${ }^{59}$ As Lawrence writes in his article, the bathroom located on the ground floor is "supplied from a cistern overhead that is filled from the roof." 60 The water for the laundry is similarly "obtained from a cistern which like that of the bathroom is supplied from the roof." 61 The Lawrence and Sutherland bathrooms are the only definite instances of Crellin incorporating these features into his farmhouses. The appearance of bathrooms in the main floor plan of both the Lawrence and Sutherland houses is a clear sign of innovation, as was the inclusion of built-in closets in four of the five upstairs bedrooms in the Lawrence house. In Smith's 1864 house plan that may have served as Lawrence's model, only one bedroom included a closet. ${ }^{62}$

More striking still, in both the Lawrence and Sutherland houses, is the development of complex, functional cellar arrangements lit by prominent windows and paved with cement floors. Crellin's earlier houses reveal that cellars were dug out and included windows while others were partially excavated with crawlspaces under the kitchen wing. Most had earthen floors while the Seaton house has a partially dug out cellar with a flagstone floor. As Lawrence wrote in 1894, his cellar floor was made of Portland cement (a first for Crellin). In the 1880s, The American Architect and Building News featured articles such as "The Adhesive Strength of Portland Cement" and "A New Method for Manufacturing Portland Cement" that Lawrence may have read. ${ }^{63}$ By 1893, Portland cement was available from the London firm of George T. Mann, suggesting that Lawrence and Sutherland were early adopters of this new material. ${ }^{64}$ Cement floors heralded the beginning of the end of extensions on the back of farmhouses. The Lawrence house cellar is divided into "five connecting compartments" 65 and includes a milk room with a dumb waiter to the pantry above, a furnace room, and storage areas for apples, potatoes, and firewood. It is accessed by two staircases inside the house, one from the kitchen, the other being a continuation of the main staircase at the front of the house leading down to the laundry room, which contained a cement tub fed by a cistern. With these improvements, cellars were becoming a functioning part of the house. Lawrence emphasized this on his house exterior by showing all six, partially above ground cellar windows, each articulated with prominent flattened segmental arches embellished with the same white St. Mary's limestone voussoirs as the windows above. It is clear that in 1891, cellars were becoming more functional and that plumbing was finding its way into new homes in rural Ontario.

\section{AN EXCEPTIONAL FARMER- CLIENT: DAVID LAWRENCE}

\footnotetext{
"Our country is now about to take its place as one of the great Confederations of the earth. Let us show the world that with our rural architecture as well as agricultural progress, we can hold our place on this continent at least."

-Smith, The Canada Farmer. ${ }^{66}$
}

David Lawrence [1849-1915] (fig. 21) was born on a farm near Farnell, County Forfar, Scotland, and upon completion of his schooling spent a year in the office of architect William Fettis in nearby Brechin, 65 kilometres south of Aberdeen. After immigrating to Canada in 1873, Lawrence married Christina McKay and established himself on a farm on the northern edge of Thamesford. Although his principal occupation was farming, Lawrence developed many business, religious, and civic interests, becoming a prominent resident of the Thamesford area. As the Thamesford correspondent for the Woodstock Sentinel Review beginning in 1881, he contributed many (unsigned) articles over the years, ${ }^{67}$ including a sequence of five describing conditions in the United Kingdom written in 1893 during one of his several trips back to Scotland. ${ }^{68}$ 


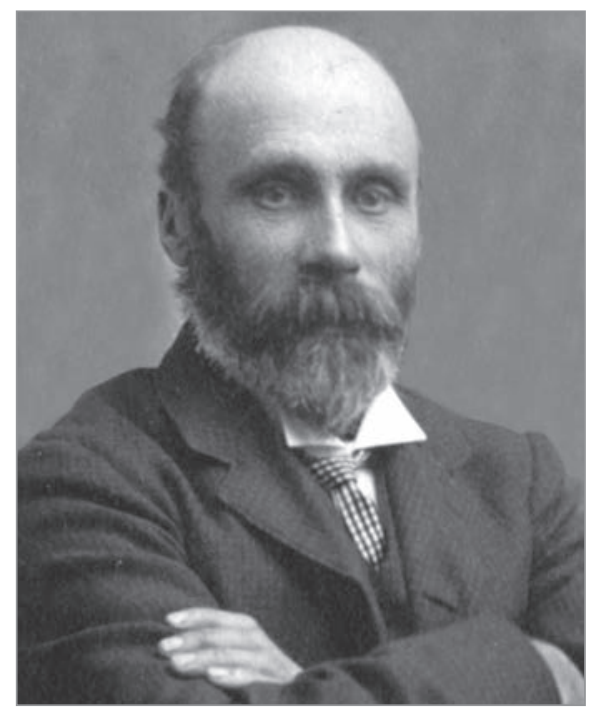

FIG. 21. DAVID LAWRENCE. | SPECIAL THANKS TO LISA BICUM AND THE LAWRENCE FAMILY.

Most significant for this analysis of Crellin's houses, Lawrence published a detailed description of his own house in the July 1894 issue of the American Agriculturist (signed "David Lawrence, Ontario, Canada"). ${ }^{69}$ As noted above, the article is illustrated with plans of the interior spaces, a section of a selfcleaning cistern, one construction photograph taken at the point when most of the masonry was finished and before the roof structure was started (fig. 22), and one photograph of the completed house (fig. 7). Through Lawrence's writings, we are able to gain not only a sense of his interests and personality, but also a clear understanding of the decision-making process behind the design of his house.

Given his early work experience in Scotland, Lawrence no doubt possessed far more knowledge about architecture than any of Crellin's other clients. In an interview published in the Woodstock Weekly Sentinel Review in 1904, Lawrence stated that he had "prepared plans and specifications for quite a number of dwelling houses, the training he received

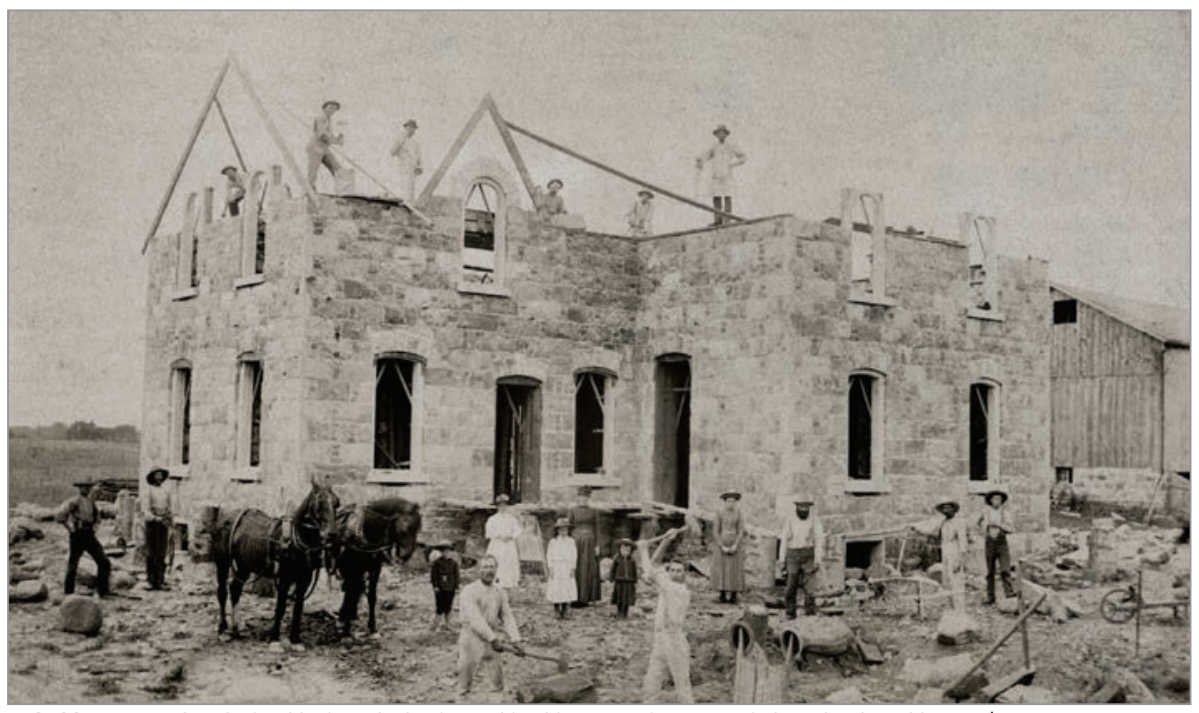

FIG. 22. LAWRENCE HOUSE, CONSTRUCTION SITE, 1891, 205 ALLEN ST., THAMESFORD, OXFORD COUNTY. | AMERICAN AGRICULTURIST, 1894, SPECIAL THANKS TO LISA BICUM AND GEOFF ELLIS.

in an architect's office fitting him for such work."70 In the same interview, he said that in 1875 he was secretary to the building committee of the Presbyterian Church (now lost) in Thamesford, and he "took a very prominent part in the building of that brick church."71 As the early construction photo of the Sutherland house reveals, we know of at least one house other than his own where Lawrence was involved in the planning process (fig. 20).

Details from Lawrence's life and publications allow us to better understand the potential role of clients in the evolution of rural houses. ${ }^{72}$ In his 1894 article, Lawrence wrote how his original frame house (still standing across the road from his Crellin-built house) was adequate when his family was small. Lawrence's farm property had a good collection of field stones, so it was decided to build in stone. First, he "went around to see the greater part of the best houses that he had heard of, in order, if possible, to be able to group as many of the latest improvements and conveniences into one complete whole."73 Lawrence then "put the house on paper using the drawing materials he had in his desk."74

Of all the Crellin farmhouses, the Lawrence and Sutherland houses are the most distinctive in plan. Lawrence published plans of the cellar, first floor, and second floor of his house, which permits us to understand the unusual room arrangement and other major innovations (fig. 23). In both houses, the original main staircases with their winding stairs, carved newel posts, and delicately turned spindles crafted by Crellin still intact, ascend to the second floor bedrooms. These staircase halls are accessed directly from the veranda, thus separating vertical circulation from the main floor of each house. From the dining room, seven doors lead clockwise to the main staircase and the veranda on the east side facing the road; to a library and bathroom on the south side; to the kitchen on the west; and to a pantry and parlour on the north side. Lawrence's concept is close to a "medieval hall" plan and may have been influenced by the Arts and Crafts Movement or currents in American domestic architecture after 


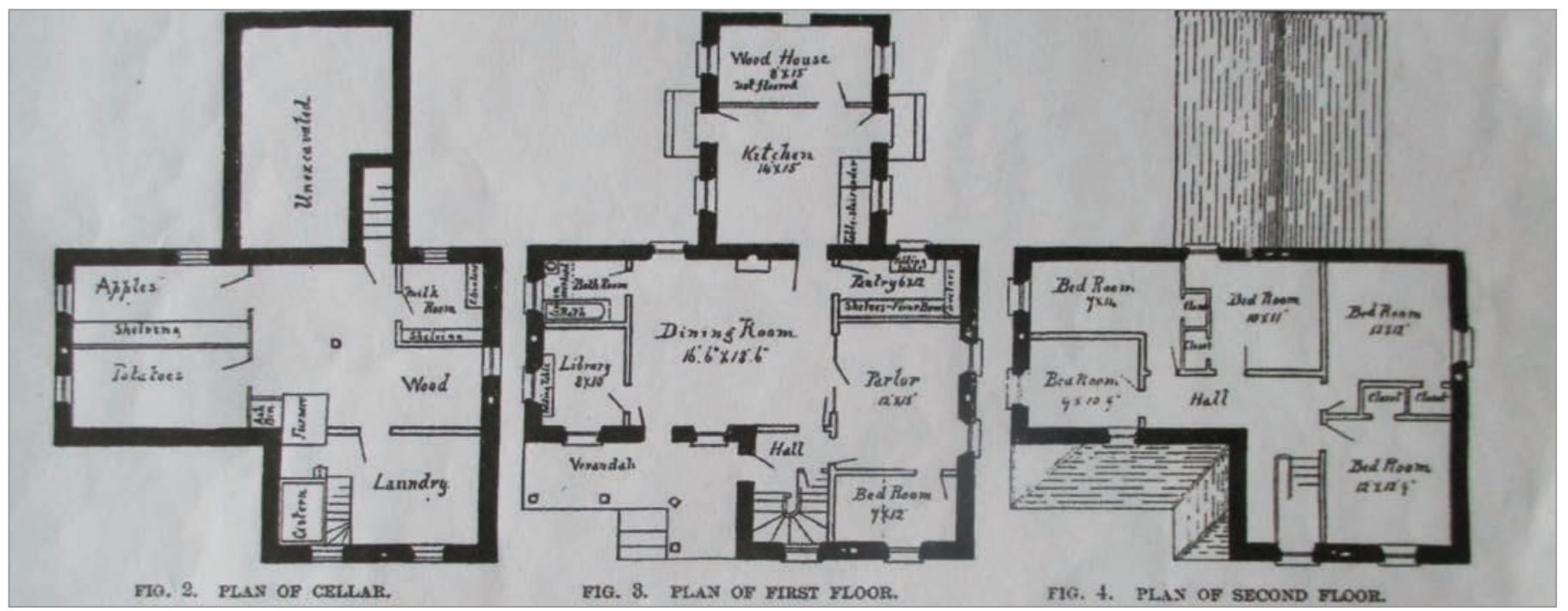

FIG. 23. LAWRENCE HOUSE PLANS, AMERICAN AGRICULTURIST, 1894. | THANKS TO LISA BICUM AND GEOFF ELIS.

1870 that sought to achieve "a new style" or "no style" with new kinds of massing and open planning..$^{75}$ Or, Lawrence may have been inspired by the "pair house" brought to Utah by Scandinavian immigrants in the last half of the nineteenth century. It had a single large square room front to back flanked axially by smaller rooms. ${ }^{76}$ In my examination of American pattern books and house designs published in the American Agriculturist, none includes a plan that could have been an obvious model for the Lawrence house.

As Lawrence continued in his article, a stone house was not cheap, even if the stones were free. He noted: "There are about four hundred and fifty perches of stone work which cost about a dollar a perch; this includes the dressing of corners and arches but not the sills." 77 The slate and slating costs were over two hundred dollars, the carpenter's labour about two hundred dollars, the plumbing, over sixty dollars. Lawrence estimated that "two thousand dollars did not pay for all that had to be paid for . . "78 He also remarked that "there was something like one thousand six hundred meals served to the tradesmen while working at the house."79 Throughout the building process, Lawrence's wife Christina was probably an exhausted hero in the kitchen. Finally, Lawrence stated that although a stone house is not the cheapest, he believed it to be the best: "it is cool in the summer, warm in the winter, and always dry." ${ }^{80}$

Lawrence was evidently proud of his house, believing he had built the ideal home for his family. His 1894 article for the American Agriculturist is testament to his creativity and careful attention to detail in the design of his house. ${ }^{81} \mathrm{His}$ article stresses practicality, modernity, convenience, and cost, demonstrating how, without a fully qualified architect, a sophisticated, custom-designed and built house could be created and become a pattern-book model for others. Three months after being published in the American Agriculturist, the complete article appeared in Australia in The Sydney Mail newspaper, a remarkable tribute to the global nature of media circulation in the late nineteenth century ${ }^{82}$
In addition to mass print media, the railway also linked Ontario farm communities to the world beyond. Not only could farmers like Lawrence travel quickly to urban centres in the region where new buildings, products, and publications could be found to serve as inspiration, but urban travellers from the comfort of railcars could gaze over the rural landscape and glance at the changes wrought by agricultural policies, rising wealth, and aesthetic ideas transported to the countryside through sources like The Canada Farmer. As a participant in the shaping of this modern vision of the world, David Lawrence capitalized on the new Canadian Pacific Rail-Line that passed along the northern edge of Thamesford and along the southern edge of his property, which in 1891 linked Toronto to London, Detroit, and beyond. Passengers travelling from Toronto to London were given a perfect view of Lawrence's house, passing within less than thirty metres of the main façade as their train crossed over the Middle Thames River. Clothed in Crellin's striking, colourful, patterned Aberdeen Bond masonry, Lawrence might have regarded his as the 
most up-to-date farmhouse in Oxford County, if not the province. Canadian rail passengers as well as readers in the United States and Australia were invited to judge for themselves.

\section{CONCLUSION}

The foregoing analysis of John Thompson Crellin's stone farmhouses reveal a complex design dynamic in the rapidly changing world of late nineteenth-century rural Ontario. Since these houses can be dated, it is possible to show a significant evolution over a twenty-year period. The houses are the embodiment of Ruskin's ideas about stone walls, pattern, colour, and honouring the craftsman; Crellin was the "zealous and happy workman" 83 that Ruskin admired. James Avon Smith's determination to beautify the countryside by developing The Canada Farmer house designs was a driving force for change. The exceptional group of farmer-clients who hired Crellin to build their houses participated in larger, international design trends, benefitted from developments in transportation, mass-production, technological innovation, and used print media to shape their visions of how to live well. The dissemination of texts, drawings, and photographs describing David Lawrence's house to audiences in the United States and Australia underline the linkages between far-flung corners of the globe in which the Southern Ontario farm economy was becoming increasingly integrated.

\section{NOTES}

1. I would like to thank my son Christopher Drew Armstrong, Associate Professor of History of Art and Architecture at the University of Pittsburgh, for reviewing and providing comments on this article. I would also like to thank the homeowners of all of the Crellin houses for opening their homes to me and for providing answers. (There are 13 homeowners listed because one of the houses was sold during the time I was researching the article. One owner gave me information on the house and the second owner gave me access to the house). Joan and John Alderman; Lisa Bicum and Geoff Ellis; Robyn and Gary Boulton; Shannon and David Green; Katherine and James Grieve; Jane and Donald Guthrie; Ken Judge; Kathryn and Steve MacDonald; Ulrike and Carl Pelkmans; Doris Seaton; Dianne and Douglas Towle; Amy and Jordan Van De Kemp; Dianne and James Wheler. I would like to express my gratitude to the Crellin family, especially Alice Crellin Ingle, Suzanne Crellin Taylor, Krista Crellin, and Glen Crellin. Many thanks to Hugh McVittie and John Alexander Lawrence, grandsons of David Lawrence, for photographs and information on David. My thanks to Professor Emeritus of Geology Gerard V. Middleton at McMaster University for giving me an on-site course and extensive information on the stone used by Crellin. Lastly, I would like to thank my husband Robin L. Armstrong, Professor Emeritus at the University of Toronto, who took many of the photographs and edited the manuscript. For those unfamiliar with the Oxford County farm addresses identified in the figures, the roads run east and west, the lines run north and south. Each farm has a blue sign at the farm gate with the road or the line number in the first two digits followed by a space then the farm address in the last four digits.

2. For further information, please contact the author at k.armstrong803@gmail.com.

3. Ruskin, John, 1885, The Stones of Venice, New York, John B. Alden, vol. 1, p. 52.

4. Kalman, Harold, 1994, A History of Canadian Architecture, vol. 2, Toronto, Oxford University Press, p. 604.

5. The Canada Farmer, 1873, vol. 10, no. 1, p. 7.

6. The Canada Farmer, 1873, vol. 10, no. 6, p. 98

7. The Canada Farmer, 1873, vol. 10, no. 1, p. 7.

8. Hitchcock, Henry-Russell, 1978, Architecture: Nineteenth and Twentieth Centuries, New York, Penguin Books, p. 160.
9. The Canada Farmer, 1866, vol. 3, no. 2, p. $20-21$; 1868, vol. 5, no. 2, p. 28.

10. The Canada Farmer, 1868, vol. 5, no. 2, p. 28.

11. The Canada Farmer, 1869, vol. 1, no. 12, p. 450.

12. Mace, Jessica, 2013, "Beautifying the Countryside, Rural and Vernacular Gothic in Late Nineteenth-Century Ontario," Journal of the Society for the Study of Architecture in Canada, vol. 38, no. 1, p. 36.

13. Weir, Scott, 2016, "The Picturesque Gothic Villa Comes to Town: The Emergence of Toronto's Bay-and-Gable House Type," Journal of the Society for the Study of Architecture in Canada, vol. 41, no. 1, p. 58-59.

14. The Canada Farmer, 1867, vol. 4, no. 12, p. 189.

15. Weir, "The Picturesque Gothic Villa Comes to Town," p. 59.

16. Wadsworth, Unwin and P.L.S. Brown, 1876, Topographical and Historical Atlas of the County of Oxford, Ontario, Toronto, Walker \& Miles, n.p. Crellin is listed as a builder and contractor.

17. Ruskin, The Stones of Venice, p. 51.

18. 1841 English Census.

19. Mather, Ian and Margaret Crellin, London, England, private communication, November 30, 2012. Thank you.

20. Wadsworth and Brown, op. cit. The date 1869 is given for Crellin's arrival in Canada."

21. McCormick, Veronica, 1968, A Hundred Years in the Dairy Industry 1867-1967, Ottawa, Dollico, p. 11-14.

22. The Canada Farmer, 1872, vol. 4, no. 11, p. 403.

23. "Suburban Villa or Farm House," The Canada Farmer, 1864, vol. 1, no. 9, p. 132.

24. Upton, Dell, 1984, Pattern Books and Professionalism: Aspects of the Transformation of Domestic Architecture in America 18001860, Chicago, University of Chicago Press, p. 144-149.

25. "A Cheap Farm House," The Canada Farmer, 1864 , vol. 1, no. 22, p. 340.

26. "A Two Story Farm House," The Canada Farmer, 1865, vol. 2, no. 8, p. 116-117.

27. "A Cheap Country House," The Canada Farmer, 1868 , vol. 5 , no. 16 , p. $244-245$.

28. "Design of a Small Farm Dwelling," The Canada Farmer, 1871, vol. 3, no. 1, p. 16. 
29. Downing, Andrew Jackson, 1859, The Architecture of Country Houses, New York, Appleton, p. 300.

30. Ruskin, John, 1989, The Seven Lamps of Architecture, New York, Dover, p. 77.

31. Naismith, Robert J., 1985, Buildings of the Scottish Countryside, London, Victor Gollancz, p. 84-85.

32. Mackenzie, Hugh, 1953, The City of Aberdeen, Edinburgh, Oliver and Boyd, p. 230-231.

33. Ruskin, The Seven Lamps, p. 83.

34. Id., p. 81

35. Id., p. 137.

36. Id., p. 24.

37. Hitchcock, Architecture: Nineteenth and Twentieth Centuries, p. 248.

38. Henderson Floyd, Margaret, 1997, Henry Hobson Richardson: A Genius for Architecture, New York, The Monacelli Press Inc., p. 12, 50, 251.

39. Robert Watt, master stonemason, private communication, April 13, 2015.

40. Meeting with Robert Montaque, July 10, 2014. Thank you for showing me Crellin's Aberdeen Bond barn foundation on the $13^{\text {th }}$ line, no. 6332, Oxford County.

41. Nancy and Victor West, thank you. Their 1883 brick house located just north of the Towle house has a stone foundation built by Crellin.

42. The Canada Farmer, 1873, vol. 10, no. 6, p. 98. A quote from A.J. Downing.

43. See Tausky, Nancy Z. and Lynne D. DiStefano, 1986, Victorian Architecture in London and Southwestern Ontario, Symbols of Aspiration, Toronto, University of Toronto Press.

44. Id., p. 162-165.

45. Id., p. 177-179

46. Id., p. $163,164,178$.

47. Id., p. 83-86.

48. Downing, The Architecture of Country Houses, p. 181. Floral motif: the Towle house. Fish scale design: the David Lawrence house and the Alexander Sutherland house.

49. Ruskin, The Seven Lamps, p. 5, 20-21, 169-170, 174-175.

50. Private communication with Robert Kordyban, 2012, Thamesford, Ontario, Thank you.

51. The Canada Farmer, 1873, vol. 10, no. 6, p. 98.
52. The Canada Farmer, 1868, vol. 5, no. 16, p. 244-245.

53. Arthur, Eric and Thomas Ritchie, 1982, Iron: Cast and Wrought Iron in Canada from the Seventeenth Century to the Present, Toronto, Buffalo, London, University of Toronto Press. Heater with oven (p. 181) is the same as the one in the Lawrence house which was probably delivered to the door by Eaton's.

54. Ruskin, The Stones of Venice, p. 8.

55. I would like to thank Ken Judge, owner of the Alexander Sutherland house, and Gordon Whitehead, who lived there in the 1950s, for their assistance in figuring out how the house interior looked in 1891.

56. The Canada Farmer, 1864, vol. 1, no. 9, p. 132.

57. Tausky and DiStefano, Victorian Architecture in London, p. 86-87.

58. Id., p. 97.

59. The Canada Farmer, 1868, vol. 5, no. 16, p. 244-245.

60. Lawrence, David, "How the New House Was Built," American Agriculturist, 1894, New York, vol. 53, no. 7, p. 375-376.

61. Ibid.

62. The Canada Farmer, 1864, vol. 1, no. 9, p. 132.

63. Reiff, Daniel D., 2000, Houses from Books, Treatises, Pattern Books, and Catalogs in American Architecture, 1738-1950: A History and Guide, The Pennsylvania State University Press, University Park, Pennsylvania, p. 133.

64. Tausky and DiStefano, Victorian Architecture in London, p. 96-97. For the George T. Mann company, see the map titled: "City of London, Canada, With Views of Principal Business Buildings," Toronto, Toronto Lithographing Co., 1893. Among the businesses illustrated is the George T. Mann company (located at the corner of York and Burwell Streets, adjacent to a major rail line), which, in addition to coal, coke, wood, plaster, and fire brick, also sold Portland cement: [https://ir.lib.uwo. ca/mdc-London-maps/1], accessed August 21, 2018.

65. American Agriculturist, 1894, New York, vol. 53 , no. 7 , p. 375-376.

66. The Canada Farmer, 1867, vol. 4, no. 4, p. 60.

67. Woodstock Evening Sentinel Review, 1898, three articles of January 8.

68. Woodstock Evening Sentinel Review, 1893, February 27, March 6, March 13, March 14, March 20 (all signed with the initials "D.L.").
69. Lawrence, "How the New House Was Built," p. 375-376.

70. Woodstock Weekly Sentinel Review, 1904, November 10.

71. Ibid.

72. I would like to thank Lisa Bicum and Geoff Ellis, owners of the Lawrence house, for giving me copies of all the information they have on their house (given to them by the Lawrence family).

73. American Agriculturist, 1894, New York vol. 53 , no. 7 , p. 375

74. Hugh McVittie, a David Lawrence grandson, private communication, July 10, 2014.

75. Kornwolf, James D., 1986, In Pursuit of Beauty, Americans and the Aesthetic Movement, Museum of Modern Art, New York, Rizzoli International Publications, p. 340-384.

76. Upton, Pattern Books and Professionalism, p. 142.

77. American Agriculturist, 1894, New York vol. 53 , no. 7 , p. 376 .

78. Ibid.

79. Ibid.

80. Ibid

81. Id., p. $375-376$

82. The Sidney Mail, 1894, Sidney, Australia, October 20. My thanks to Robin E. Cooper at the University of Guelph.

83. Ruskin, Seven Lamps, p. 5, 20-21, 169-170, 174-175. 